\title{
REFERENCES
}

Crabtree, H. G. (1944). Cancer Res. 4, 688.

Crabtree, H. G. (1945). Cancer Res. 5, 346.

Crabtree, H. G. (1946). Cancer Res. 6, 553.

Coombs, H. I. \& Hele, T. S. (1927). Biochem. J. 21, 611.

Folin, O. \& Marenzi, A. D. (1929). J. biol. Chem. 83, 103.

Haddow, A., Elson, L. A., Roe, E. M. F., Rudall, K. M. \& Timmis, G. M. (1945). Nature, Lond., 155, 379.

Lightbody, H. D. \& Lewis, H. B. (1929). J. biol. Chem. 82, 663.
McGuinn, A. \& Sherwin, C. P. (1933). Proc. Soc. exp. Biol., N.Y., 30, 1115 .

Miller, G. L. \& du Vigneaud, V. (1939). J. biol. Chem. 127, 685.

Smuts, D. B., Mitchell, H. H. \& Hamilton, T. S. (1932). J. biol. Chem. 95, 283.

Stekol, J. A. (1936). J. biol. Chem. 113, 279.

Stekol, J. A. (1943). Arch. Biochem. 2, 151.

Winneck, P.S. \& Smith, A. H.(1937a). J. biol. Chem. 119, 93.

Winneck, P. S. \& Smith, A. H. (1937b). J. biol. Chem. 121, 345.

\section{The Intermediary Metabolism of the Mammary Gland}

\section{ACETATE METABOLISM OF LACTATING MAMMARY GLAND SLICES WITH SPECIAL REFERENCE TO MILK FAT SYNTHESIS}

\author{
By S. J. FOLLEY AND T. H. FRENCH \\ National Institute for Research in Dairying, University of Reading
}

(Received 21 November 1949)

The origin of milk fat has been studied by various techniques (see review by Folley, 1949), the most favoured hitherto being the arterio-venous (A.v.) method which, however, can give little insight into the synthetic mechanisms involved. Arterio-venous studies have disproved the earlier idea of the utilization of blood phospholipin fatty acids for milk fat synthesis and have provided evidence that fatty acids of neutral fat, probably belonging to the glyceride fraction, are absorbed from the blood by the lactating udder, and are there transformed into glycerides of milk fat (see reviews by Folley, 1940, 1949).

Because they obtained a high respiratory quotient (R.Q.) by the A.v. method for the lactating goat udder, Graham, Houchin, Peterson \& Turner (1938) postulated the formation of fat from carbohydrate by the lactating mammary gland (see also Reineke, Stonecipher \& Turner, 1941). In apparent agreement with this finding, which had meanwhile been confirmed for the cow by other workers (see Folley, 1949), were the in vitro results of Folley \& French $(1948 a, b, 1949 c)$, who showed that lactating mammary slices from non-ruminants (mouse, rat, rabbit and guinea pig) utilize glucose in vitro with R.Q. $>1$, results which were also interpreted as indicating the synthesis of fat from carbohydrate. The situation was, however, complicated by the fact that mammary gland slices from ruminants (cow and goat) were found to be practically inert towards glucose in vitro. As far as ruminants are concerned, therefore, these slice experiments provided no evidence to support in vivo indications of fat synthesis from carbohydrate, and threw little light on the nature of the precursors of milk fat.

Tracer studies have provided evidence of the utilization of acetate for fatty-acid synthesis in the mammal both in vivo (Rittenberg \& Bloch, 1945) and in liver slices in vitro (Bloch \& Kramer, 1948). Moreover, it is now known that in ruminants large quantities of acetic acid are produced in the rumen by fermentation of cellulose (Elsden \& Phillipson, 1948) and that this acetate can be absorbed, leading to appreciable arterial blood levels (Reid, 1950, for sheep; McClymont, 1949, for cow). The possibility, arising mainly from the first of these tracer studies, that acetate is utilized by the mammary gland for milk fat synthesis was suggested by Folley (1945).

This paper deals with the acetate metabolism of mammary gland slices from various species, and presents evidence for the utilization of acetate for milk-fat synthesis by the lactating mammary gland. Part of this work has already been reported in preliminary communications (Folley \& French, $1948 c$, $1949 a, b)$ in the first two of which attention was drawn to the significance of these results for the origin of the short-chain fatty acids, which, as shown principally by Hilditch and his co-workers (Hilditch, 1947), are a prominent feature of the milk fat of herbivorous animals (although absent from body fat), and the origin of which has been the subject of controversy (see discussion by Folley, 1949). If acetate is utilized for milk-fat formation in the mammary gland, it seems probable that the short- 
chain acids are intermediates in the formation of higher fatty acids by condensation of acetate or some 2-carbon derivative thereof (Folley, 1945).

More recently this theory of the origin of the short-chain acids of milk fat has been confirmed by tracer experiments. Popják \& Beeckmans (1949b) have demonstrated the incorporation of injected acetate labelled with ${ }^{14} \mathrm{C}$ into the glyceride fatty acids isolated from the mammae of 28-day pregnant rabbits. Fractions representing the short-chain acids have subsequently been isolated from these fatty-acid samples and shown to contain higher proportions of isotopic carbon than the non-volatile residues (Popják, Folley \& French, 1949). These results leave very little room for doubt that shortchain fatty acids of milk fat can be formed in the mammary gland by condensation of acetate or of a reactive derivative thereof, and in this respect are in harmony with the conclusions drawn from the results presented in this paper.

\section{EXPERIMENTAL}

Manometric methods. Quotients $\left(Q_{\mathrm{O}_{2}}\right.$, and $\left.Q_{\text {acid }}^{\mathrm{o}_{2}}\right)$, calculated in $\mu \mathrm{l} . / \mathrm{mg}$. final dry weight/hr., and R.Q. were determined by the method of Dickens \& Simer (1931) which has the advantage that the value for $Q_{\text {acid }}^{\mathbf{O}_{2}}$ gives an estimate of the utilization of a single consumable anion, such as acetate, if it is used as substrate. The values of $Q_{\text {acid }}^{o_{2}}$, used throughout this work as a measure of the acetate utilization, probably somewhat underestimate the latter, since this quotient is a resultant of acid production and utilization by the slice, and we have found that mammary gland slices invariably produce some acid when incubated with carbohydrate or without substrate (Folley \& French, 1949c). Nevertheless, this uncertainty clearly does not affect the conclusions drawn from the results.

The general manometric technique was that used before (Folley \& French, 1949c), the gas phase being $5 \% \mathrm{CO}_{2}$ in $\mathrm{O}_{2}$, temperature $37^{\circ}$, and the medium the saline-bicar- bonate of Krebs \& Henseleit (1932). Most determinations were done in duplicate and all lasted for $3 \mathrm{hr}$. $\mathrm{Na}$ acetate was used in $0.02 \mathrm{M}$ final concentration throughout. The acetate solutions were prepared by saturating an aqueous $0.2 \mathrm{M}$ solution with the gas mixture at $37^{\circ}$, then adjusting to pH 7.4 (glass electrode) with solid $\mathrm{Na}_{2} \mathrm{CO}_{3}$. This solution (1 vol.) was added to Krebs saline-bicarbonate (9 vol.).

Animals. Abdominal mammary tissue was obtained and sliced as before (Folley \& French, 1949c) from hooded Norway rats killed at the fourteenth to twenty-first days of lactation, and from Dutch rabbits killed at various stages. Samples of udder tissue were obtained from lactating 'scrub' goats, whose stages of lactation were unknown, but were probably 8-9 months. The goats were milked twice daily up to the time of slaughter when they were shot and the udder tissue removed immediately. In three cases udder tissue was obtained from living goats under cyclopropane anaesthesia. Udder tissue samples were removed, under cyclopropane anaesthesia, at various known times after parturition from sheep which were suckling lambs, and a final sample taken from each at slaughter under the same conditions as cows (see below). All the sheep samples were obtained in early lactation. Special arrangements were made for cows of known history to be slaughtered in milk. All were of necessity in late lactation (Folley \& French, 1949c), but wherever possible animals giving at least $10 \mathrm{lb}$. $(4 \cdot 5 \mathrm{~kg}$.) of milk daily were selected. They were milked twice daily up to the morning of slaughter. At death the udder was at once removed and slices of alveolar tissue cut at the abattoir and brought to the laboratory in oxygenated saline-bicarbonate at room temperature. The extra delay from animal to manometric flask was of the order of $10 \mathrm{~min}$.

\section{RESULTS}

\section{Non-utilization of glucose by lactating mammary gland slices from ruminants}

We have previously reported (Folley \& French, $1949 \mathrm{c}$ ) that lactating mammary gland slices from the goat and cow hardly utilize glucose in vitro as shown by the low $Q_{\mathrm{O}_{2}}$ and the fact that the R.Q. is below

Table 1. Respiration of lactating mammary gland slices from ruminants in presence of glucose (0.3\%)

\begin{tabular}{|c|c|c|c|c|c|c|c|c|c|}
\hline \multirow[b]{2}{*}{ Animal } & \multirow[b]{2}{*}{ Stage of lactation } & \multirow{2}{*}{$\begin{array}{c}\text { No. of } \\
\text { animals }\end{array}$} & \multirow{2}{*}{$\begin{array}{l}\text { No. of } \\
\text { determi- } \\
\text { nations }\end{array}$} & \multicolumn{2}{|c|}{$-Q_{O_{2}}$} & \multicolumn{2}{|c|}{$Q_{\text {acdd }}$} & \multicolumn{2}{|c|}{ R.Q. } \\
\hline & & & & Mean* & Range & Mean & Range & Mean & Range \\
\hline Sheep & $7-47$ days & 4 & $15 \dagger$ & $3 \cdot 9 \pm 0 \cdot 3$ & $2 \cdot 0-5 \cdot 2$ & $1 \cdot 9 \pm 0.2$ & $0.7-2.9$ & $0.88 \pm 0.01$ & $0.69-1.05$ \\
\hline Goat & $\begin{array}{l}\text { Advanced lactation: } \\
\text { stages unknown }\end{array}$ & 11 & $11 \ddagger$ & $4 \cdot 9 \pm 0 \cdot 3$ & $3 \cdot 2-6 \cdot 2$ & $1 \cdot 6 \pm 0 \cdot 1$ & $1 \cdot 0-2 \cdot 5$ & $0 \cdot 86 \pm 0 \cdot 03$ & $0.69-0.95$ \\
\hline Cow & $\begin{array}{l}\text { Advanced lactation: } \\
\text { includes } 3 \text { cows } \\
\text { giving no more than } \\
5 \mathrm{lb} .(2 \cdot 3 \mathrm{~kg} .) \\
\text { milk } / \text { day at slaughter }\end{array}$ & r & 9 & $2 \cdot 7 \pm 0 \cdot 4$ & $1 \cdot 5-4.7$ & $1.9 \pm 0.2$ & $1 \cdot 0-2 \cdot 8$ & $0.84 \pm 0.03$ & $0.64-0.93$ \\
\hline Cow & $\begin{array}{l}\text { Advanced lactation: } \\
\text { milk yield at } \\
\text { slaughter approxi- } \\
\text { mately } 10 \mathrm{lb} . \\
(4 \cdot 5 \mathrm{~kg} .) / \text { day }\end{array}$ & 6 & 6 & $3 \cdot 1 \pm 0 \cdot 5$ & $2 \cdot 0-4 \cdot 7$ & $1.9 \pm 0.2$ & $1 \cdot 0-2 \cdot 3$ & $0.84 \pm 0.04$ & $0.64-0.93$ \\
\hline
\end{tabular}


unity, though of course glucose may be utilized for lactose formation. Table 1 includes these and additional data for the goat and cow, together with entirely new data for sheep. Of the latter fifteen determinations, eleven were on biopsy material obtained from sheep under cyclopropane anaesthesia, but these, and also the determinations in presence of acetate (see below), fit very well with the terminal values on tissue obtained at slaughter, so there is no evidence that cyclopropane affected the metabolism of mammary tissue taken at biopsy.

Table 1 shows clearly that ruminant mammary tissue oxidizes very little glucose in vitro and that the R.Q. is low. The possibility that the cow and goat tissue exhibited this behaviour because the tissue was from animals in late lactation is disposed of by the results on sheep all of which were studied in early lactation. This conclusion is supported by the fact that if one eliminates those three of the nine cows which gave $5 \mathrm{lb} .(2.3 \mathrm{~kg}$.) milk/day or less at slaughter, leaving six giving $10 \mathrm{lb} .(4.5 \mathrm{~kg}$.)/day and which are known to have been regularly milked up to the morning of slaughter, the mean R.Q. is no higher.

\section{Utilization of acetate by lactating mammary gland slices}

Table 2 gives results for tissue from ruminant and from two non-ruminant animals, rat and rabbit. With ruminant tissue $-Q_{\mathrm{O}_{2}}$ was greater than in the presence of glucose. There was appreciable acetate utilization as shown by negative values of $Q_{\text {acid }}$, and the mean R.Q. for each species was greater than unity. The mean R.Q. values for the goat and cow were shown by the 'one-tail' ' $t$ ' test to be significantly greater than unity (Table 2). In the case of sheep, since on three of the four animals several results were obtained at different stages of lactation, the standard errors of the means were estimated from the deviations of the weighted squares of 'animal means'. In this case also the observed mean R.Q. was significantly greater than unity. It may be concluded that ruminant mammary tissue actively utilizes acetate in vitro with high R.Q. Acetate has previously been shown to be oxidized by kidney cortex of rat and rabbit (Elliott, Benoy \& Baker, 1935) and guinea pig (Kleinzeller, 1943), but with R.Q. < l (Elliott et al. 1935).

By contrast, the results in Table 2 show that tissue from the two non-ruminant forms studied gives a low in vitro R.Q. with acetate. Rat tissue showed little or no acetate utilization, the mean $-Q_{\mathrm{O}_{2}}$ and R.Q. values for ten determinations being hardly different from the values for the endogenous respiration of mammary slices from fully lactating rats previously reported (Folley \& French, 1949c). The values for $Q_{\text {acid }}$ in acetate are indeed somewhat lower, 0.1 as against $0 \cdot 6$, but it is doubtful if this difference is sufficiently significant to allow the conclusion that

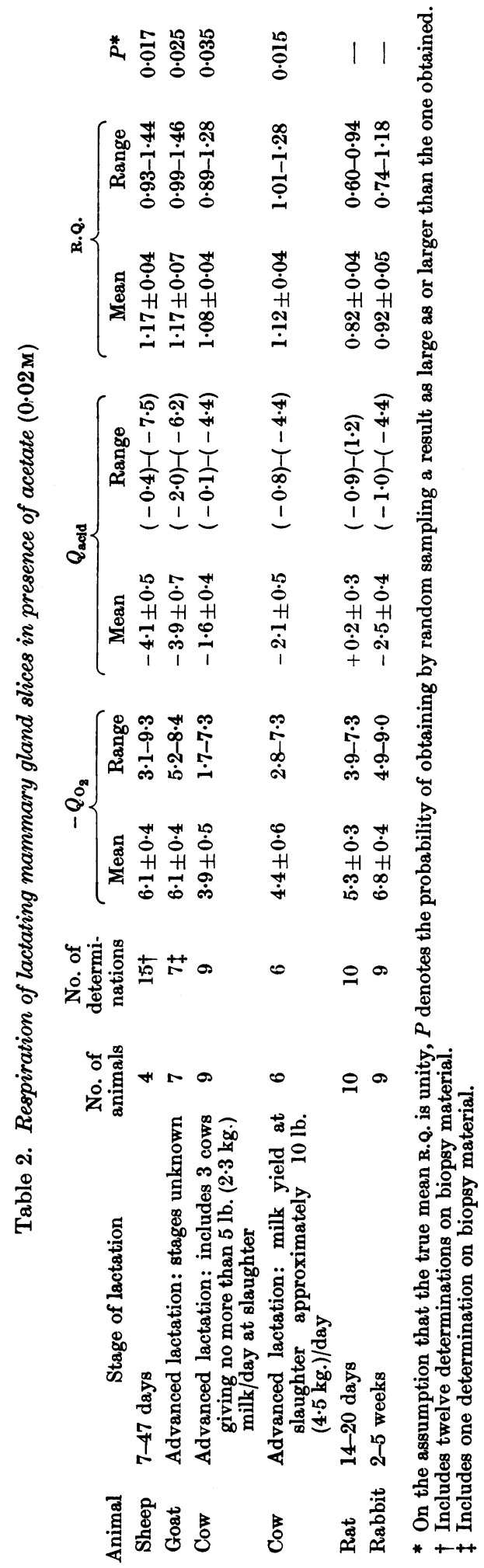


a small amount of acetate is utilized by rat tissue. Rabbit tissue seems to occupy an intermediate position between the rat and the ruminants in that though the mean R.Q. was less than unity, $-Q_{\mathrm{O}_{2}}$ was as great as in previously reported experiments with glucose as substrate (Folley \& French, 1949c), and there was an appreciable uptake of acetate.

Previous studies on rat mammary tissue (Folley $\&$ French, $1949 d$ ) have shown a progressive increase in $-Q_{\mathrm{O}_{2}}$ and R.Q. (in glucose) with advance in lactation (i.e. as the rate of milk secretion increases), at least in the earlier stages. It was therefore of in-

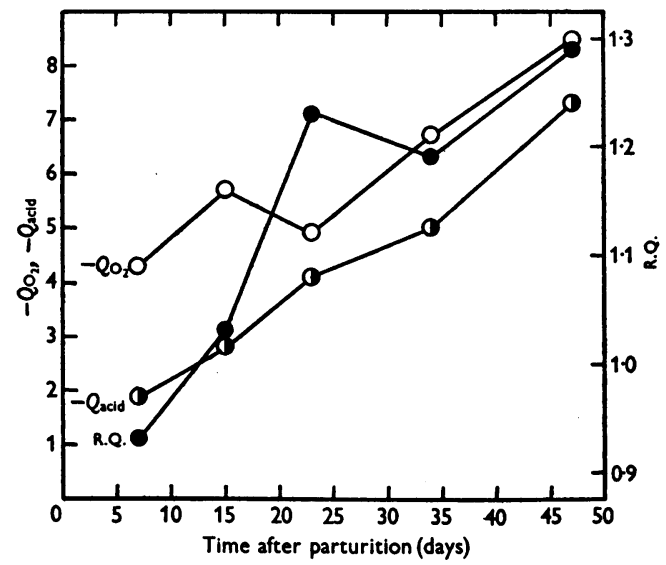

Fig. 1. Changes in respiration and acetate utilization of lactating mammary gland slices from sheep no. 1 with advance of lactation. Slices incubated at $37^{\circ}$ in salinebicarbonate at $\mathrm{pH} \mathrm{7.4}$ with $0.02 \mathrm{M}$-sodium acetate as substrate.

terest to find out if the same applies to ruminant tissue. Fig. 1 shows the relationship between stage of lactation and the quotient values in acetate for tissue from sheep no. 1, a pedigree ewe in excellent condition which was lactating well, as indicated by the growth rate of her single lamb. The period studied was from 7 to 47 days post-partum, which is before the declining phase of lactation sets in (Barnicoat, Logan \& Grant, 1949). As lactation progressed there was a progressive increase in $-Q_{\mathrm{O}_{2}}$ and acetate utilization ( $-Q_{\text {acid }}$ ) and the R.Q. increased from a value very near unity at 7 days post-partum to a value of almost 1.3 at 47 days. Incidentally these curves illustrate the concordance between values obtained with biopsy specimens and those for tissue obtained at slaughter.

Fig. 2 shows well the contrast between the progressive increase in $-Q_{\mathrm{O}_{2}}$ and R.Q. in acetate as the early phase of lactation progresses, and the constancy or slow fall in these quotients with glucose as substrate. It will be noted that both substrates gave substantially the same values at the outset (7 days).
The remaining three sheep were non-pedigree animals of unknown history, purchased from a dealer. They were in much poorer condition and they lambed down late in the season. All the available evidence indicated that these were not such good milkers as sheep no. 1, and it is not therefore surprising that the results on tissue obtained from them showed no regular correlation with advance of lactation.

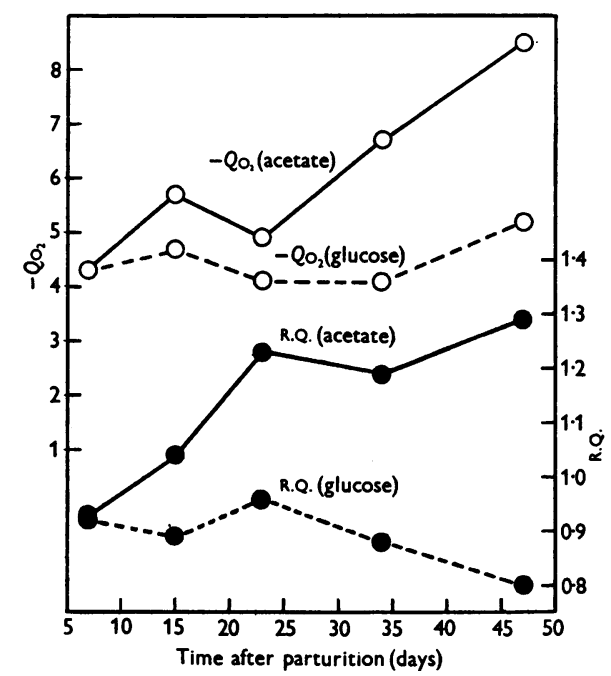

Fig. 2. Comparison of the effect of advancing lactation on the respiration of lactating mammary gland slices from sheep no. 1 in presence of $0.02 \mathrm{M}$-sodium acetate and $0.3 \%$ glucose respectively. Slices incubated at $37^{\circ}$ in saline-bicarbonate at $\mathrm{pH} \mathbf{7 \cdot 4}$.

\section{Effect of glucose on utilization of acetate by lactating mammary gland slices}

In contrast to tissue from ruminants the failure of mammary gland slices from non-ruminants to utilize acetate with high R.Q. is very intriguing. However, there are indications that rabbit mammary tissue, at least, utilizes some acetate, perhaps partly for fatty-acid synthesis, though if this is so the rate is insufficient to give a net synthesis of fat, assuming that the high R.Q. implies this. It should, therefore, be possible to find conditions under which the rate of acetate incorporation into fat by non-ruminant mammary tissue could be increased.

Bloch \& Kramer (1948) found that glucose or pyruvate increased the rate of incorporation of acetate into fatty acids by rat liver slices in vitro. We have therefore studied the effect of glucose on the utilization of acetate by lactating mammary slices from rat, rabbit and sheep. In combination with acetate $(0.02 \mathrm{M})$ various glucose concentrations were tried, but with rat and rabbit tissue, which readily utilizes glucose, a suboptimal glucose concentration $(0.1 \%)$ was used in most experiments. In sheep, 
a glucose concentration of $0.15 \%$ was used throughout this series of experiments. We have not studied the effect of pyruvate on acetate utilization because our technique can only be used for studying the utilization of a single anion.

Detailed results of experiments allowing direct comparison of results with combined and single substrates on tissue from the same animal, thus leading to $\Delta$ values for quotients, are given for rat, rabbit and sheep in Tables 3, 4 and 5 respectively. For rat and rabbit tissues, which utilize glucose but not acetate, the $\Delta$ values are (glucose + acetate) - (glucose); for sheep tissue they represent (acetate + glucose) (acetate). Table 6 gives summarized mean results for series of determinations involving each substrate alone and both combined. In this case parallel determinations on tissue from the same animal are not necessarily involved. evidence that the utilization of acetate lowered the R.Q. from the high value characteristic of glucose utilization, towards the theoretical value of unity for acetate oxidation.

Rabbit. Mean $-Q_{\mathrm{O}_{2}}$ was appreciably increased by the combined substrates over the value for either substrate alone (Table 6); this effect was observed in nine of the ten experiments recorded in Table 4. It will be noticed that for rabbit tissue the mean $-Q_{\mathrm{O}_{2}}$ was higher in $0.02 \mathrm{M}$-acetate than in $0.1 \%$ glucose and in fact equal to the value for $0.3 \%$ glucose previously reported (Folley \& French, $1949 c)$.

$Q_{\text {acld }}$ changed from an appreciable positive value in glucose to a relatively large negative value, twice as great as in acetate alone (Table 6); this large acetate uptake in presence of glucose occurred in all experiments in Table 4. These results indicate a con-

\section{Table 3. Effect of glucose on utilization of acetate by lactating mammary gland slices from rats}

(Acetate always 0.02 $\mathrm{M}$; glucose as shown in column 2. Rats 14-21 days in lactation.)

$\begin{array}{cccccccc}\begin{array}{c}\text { Rat } \\ \text { no. }\end{array} & \begin{array}{c}\text { Glucose } \\ \text { added } \\ (\%)\end{array} & \overbrace{-Q_{\mathrm{O}_{2}}} & Q_{\text {acid }} & \text { R.Q. } & \overbrace{-Q_{\mathrm{O}_{2}}}^{\text {Glucose + acetate }} & Q_{\text {acid }} & \text { R.Q. } \\ 21 & 0.05 & \mathbf{9 . 6} & 0.3 & 0.97 & 8.6 & -1.8 & 1.02 \\ 21 & 0.1 & 9.1 & 0.2 & 1.22 & 10.7 & -2.6 & 1.15 \\ 21 & 0.15 & 9.9 & 0.6 & 1.38 & 11.0 & -2.7 & 1.32 \\ 22 & 0.1 & \mathbf{8 . 4} & 0.4 & 1.49 & 9 \cdot 7 & -2.9 & 1.39 \\ 23 & 0.1 & 7.6 & 0.5 & 1.39 & 8.2 & -1.9 & 1.26 \\ 24 & 0.1 & 7.6 & 0.7 & 1.30 & 10.8 & -1.7 & 1.24\end{array}$

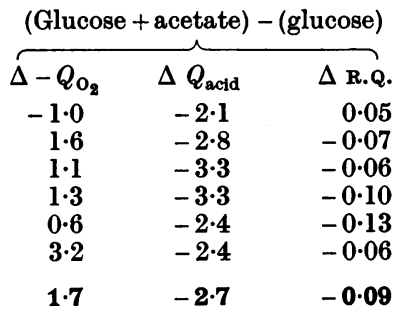

Table 4. Effect of glucose on utilization of acetate by lactating mammary gland slices from rabbits (Acetate always $0.02 \mathrm{M}$; rabbits 2-5 weeks in lactation.)

\begin{tabular}{|c|c|c|c|c|c|c|c|}
\hline \multirow{2}{*}{$\begin{array}{c}\text { Rabbit } \\
\text { no. }\end{array}$} & \multirow{2}{*}{$\begin{array}{c}\text { Glucose } \\
\text { added } \\
(\%)\end{array}$} & \multicolumn{3}{|c|}{ Glucose } & \multicolumn{3}{|c|}{ Glucose + acetate } \\
\hline & & $-Q_{\mathrm{o}_{2}}$ & $Q_{\text {acld }}$ & R.Q. & $-Q_{\mathrm{o}_{2}}$ & $Q_{\text {acld }}$ & R.Q. \\
\hline 98 & 0.05 & - & - & - & $5 \cdot 5$ & $-2 \cdot 2$ & $1 \cdot 15$ \\
\hline 98 & $0 \cdot 1$ & $4 \cdot 0$ & 1.5 & $1 \cdot 04$ & 8.8 & $-4 \cdot 3$ & $1 \cdot 30$ \\
\hline 98 & $0 \cdot 15$ & $6 \cdot 7$ & $1 \cdot 1$ & $1 \cdot 29$ & $8 \cdot 3$ & $-5 \cdot 6$ & $1 \cdot 70$ \\
\hline 94 & $0 \cdot 15$ & $5 \cdot 4$ & $0 \cdot 7$ & 1.43 & $5 \cdot 2$ & $-\mathbf{3} \cdot 0$ & $1 \cdot 68$ \\
\hline 101 & $0 \cdot 1$ & $5 \cdot 8$ & 1.8 & $1 \cdot 28$ & $10 \cdot 6$ & $-6 \cdot 3$ & $1 \cdot 20$ \\
\hline C4 & $0 \cdot 1$ & $5 \cdot 6$ & $1 \cdot 1$ & $1 \cdot 31$ & $10 \cdot 1$ & $-6 \cdot 0$ & $1 \cdot 28$ \\
\hline C5 & 0.1 & $4 \cdot 2$ & 0.6 & 1.49 & $8 \cdot 3$ & $-4 \cdot 4$ & 1.23 \\
\hline 89 & $0 \cdot 1$ & $7 \cdot 5$ & $1 \cdot 1$ & $1 \cdot 24$ & $9 \cdot 8$ & $-4 \cdot 5$ & 1.46 \\
\hline 108 & $0 \cdot 1$ & $6 \cdot 6$ & $1 \cdot 0$ & $1 \cdot 34$ & $11 \cdot 2$ & $-5 \cdot 8$ & $1 \cdot 21$ \\
\hline 114 & $0 \cdot 1$ & $4 \cdot 8$ & $1 \cdot 0$ & $1 \cdot 38$ & $8 \cdot 2$ & $-4 \cdot 5$ & $1 \cdot 17$ \\
\hline 70 & 0.1 & $5 \cdot 0$ & $1 \cdot 4$ & $1 \cdot 28$ & $8 \cdot 7$ & $-4 \cdot 0$ & $1 \cdot 35$ \\
\hline
\end{tabular}

Mean of eight determinations involving $0 \cdot 1 \%$ glucose

\begin{tabular}{|c|c|c|}
\hline \multicolumn{3}{|c|}{ (Glucose + acetate) - (glucose) } \\
\hline$\Delta-Q_{o_{2}}$ & $\Delta Q_{\text {acld }}$ & $\Delta$ R.Q \\
\hline $4 \cdot 8$ & $-5 \cdot 8$ & 0.26 \\
\hline $1 \cdot 6$ & $-6 \cdot 7$ & 0.41 \\
\hline-0.2 & $-3 \cdot 7$ & 0.25 \\
\hline $4 \cdot 8$ & $-8 \cdot 1$ & -0.08 \\
\hline $4 \cdot 5$ & $-7 \cdot 1$ & -0.03 \\
\hline $4 \cdot 1$ & $-5 \cdot 0$ & -0.26 \\
\hline $2 \cdot 3$ & $-5 \cdot 6$ & $0 \cdot 22$ \\
\hline $4 \cdot 6$ & $-6 \cdot 8$ & -0.13 \\
\hline $3 \cdot 4$ & $-5 \cdot 5$ & -0.21 \\
\hline $3 \cdot 7$ & $-5 \cdot 4$ & $0 \cdot 07$ \\
\hline 4.0 & -6.2 & -0.02 \\
\hline
\end{tabular}

Rat. Mean $-Q_{\mathrm{O}_{2}}$ was slightly greater in presence of both substrates than with glucose alone (Table 6); it was slightly increased in four experiments, hardly changed in one and decreased in one (Table 3). Presence of acetate changed $Q_{\text {acid }}$ values from small positive values to definite negative values in all experiments (Table 3), indicating an appreciable uptake of acetate in presence of glucose (Table 6). The changes in R.Q. were slight, but there was no siderable utilization of acetate by rabbit mammary tissue when glucose is present. The mean R.Q. for the combined substrates was hardly different from that for glucose, though of course higher than the value for acetate (Table 6); the $\Delta$ values were positive in five of the ten experiments recorded in Table 4, and negative in five. Here again there was no evidence that any appreciable proportion of the extra acetate was oxidized by the slices. 
Sheep. The mean $-Q_{\mathrm{O}_{2}}$ was slightly greater for the combined substrates than for acetate (Table 6); in seven experiments it was greater, approximately the same in two and slightly less in two (Table 5). The mean $-Q_{\text {acid }}$ for both substrates together was somewhat higher than for acetate alone (Table 6), this effect being apparent in seven of the eleven experiments (Table 5). R.Q. in the combined substrates was greater than in acetate (Table 6); this held for nine of the eleven experiments shown in Table 5. Therefore, in the sheep also, glucose stimulates acetate utilization by mammary gland slices.

\section{DISCUSSION}

The finding that lactating mammary gland slices from ruminants (cow and goat) fail to utilize glucose with R.Q. > 1, previously reported (Folley \& French, $1949 c)$, has been confirmed and extended to sheep in early lactation. There is therefore now no question of the indifference of ruminant mammary tissue to glucose (leaving out of account possible lactose synthesis from glucose) being due to the use of tissue taken in late lactation in which the lactation potential is low; it is clear that we are dealing with a real

Table 5. Effect of glucose on utilization of acetate by lactating mammary gland slices from sheep

\begin{tabular}{|c|c|c|c|c|c|c|c|}
\hline \multirow{2}{*}{$\begin{array}{c}\text { Sheep } \\
\text { no. }\end{array}$} & \multirow{2}{*}{$\begin{array}{c}\text { Stage of } \\
\text { lactation } \\
\text { (days) }\end{array}$} & \multicolumn{3}{|c|}{ Acetate $(0.02 \mathrm{M})$} & \multicolumn{3}{|c|}{ Glucose $(0 \cdot 3 \%)$} \\
\hline & & $-Q_{\mathrm{o}_{2}}$ & $Q_{\text {acid }}$ & R.Q. & $-Q_{\mathrm{o}_{2}}$ & $Q_{\text {acid }}$ & R.Q. \\
\hline 1 & 34 & $6 \cdot 7$ & $-5 \cdot 0$ & $1 \cdot 19$ & $4 \cdot 1$ & $2 \cdot 3$ & 0.88 \\
\hline 2 & 9 & $7 \cdot 2$ & $-4 \cdot 0$ & $1 \cdot 10$ & $4 \cdot 7$ & $2 \cdot 0$ & $0 \cdot 80$ \\
\hline 2 & 16 & $4 \cdot 7$ & $-3 \cdot 0$ & $1 \cdot 10$ & $3 \cdot 9$ & 1.8 & 0.98 \\
\hline 2 & 23 & 6.5 & $-4 \cdot 2$ & $1 \cdot 20$ & $2 \cdot 7$ & 1.5 & 0.92 \\
\hline 2 & 34 & $3 \cdot 1$ & -0.4 & $1 \cdot 01$ & $2 \cdot 0$ & $2 \cdot 9$ & 0.69 \\
\hline 3 & 10 & $6 \cdot 6$ & $-5 \cdot 1$ & $1 \cdot 28$ & $4 \cdot 2$ & $1 \cdot 2$ & 0.99 \\
\hline 3 & 17 & $5 \cdot 2$ & $-3 \cdot 2$ & $1 \cdot 22$ & $2 \cdot 9$ & $2 \cdot 2$ & 0.74 \\
\hline 3 & 24 & $4 \cdot 9$ & $-3 \cdot 6$ & $1 \cdot 26$ & $2 \cdot 4$ & $2 \cdot 4$ & 0.69 \\
\hline 3 & 32 & $8 \cdot 3$ & $-7 \cdot 5$ & $1 \cdot 44$ & $4 \cdot 1$ & $2 \cdot 3$ & 0.97 \\
\hline 3 & 43 & $9 \cdot 3$ & -5.9 & $1 \cdot 18$ & $5 \cdot 2$ & $1 \cdot 1$ & 1.05 \\
\hline 4 & 10 & $5 \cdot 5$ & $-2 \cdot 7$ & $1 \cdot 10$ & $3 \cdot 8$ & $2 \cdot 9$ & 0.85 \\
\hline
\end{tabular}

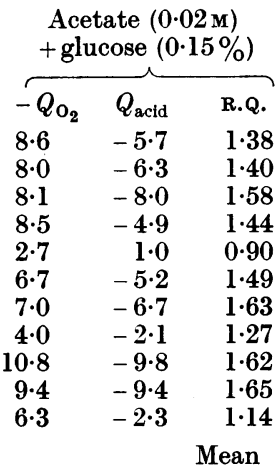

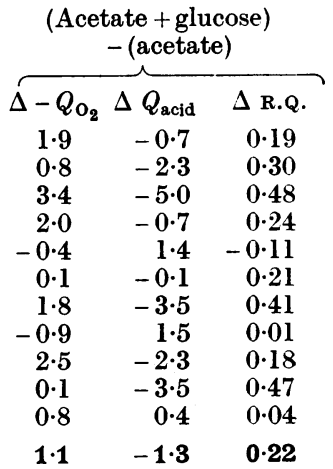

Table 6. Effect of glucose on the utilization of acetate by lactating mammary gland slices

\section{Substrate}

Glucose $(0 \cdot 1 \%)$

Acetate $(0.02 \mathrm{M})$

Glucose $(0 \cdot 1 \%)$

+ acetate $(0.02 \mathrm{M})$

Glucose $(0 \cdot 1 \%)$
Acetate $(0 \cdot 02 \mathrm{M})$
Glucose $(0.1 \%)$
+ acetate $(0.02 \mathrm{M})$

Glucose $(0 \cdot 3 \%)$

Acetate $(0.02 \mathrm{M})$

Glucose $(0 \cdot 15 \%)$

+ acetate $(0.02 \mathrm{M})$

$$
\begin{gathered}
\text { No. of } \\
\text { determi- } \\
\text { nations }
\end{gathered}
$$
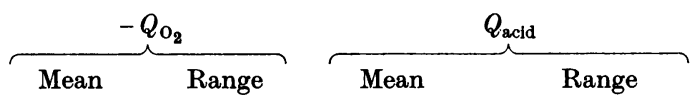

Rats: 14-21 days in lactation, seventeen animals used in all

$\begin{array}{rrrrl}5 & 8 \cdot 2 \pm 0 \cdot 3 & 7 \cdot 6-9 \cdot 1 & 0 \cdot 7 \pm 0 \cdot 3 & 0 \cdot 2-1 \cdot 8 \\ 10 & 5 \cdot 3 \pm 0 \cdot 3 & 3 \cdot 9-7 \cdot 3 & 0 \cdot 2 \pm 0 \cdot 3 & (-0 \cdot 9)-1 \cdot 2 \\ 8 & 9 \cdot 7 \pm 0 \cdot 4 & 8 \cdot 2-10 \cdot 9 & -2 \cdot 3 \pm 0 \cdot 3 & (-1 \cdot 1)-(-3 \cdot 5)\end{array}$

Rabbits: 2-5 weeks in lactation, twenty-six animals used in all

$\begin{array}{rrrrr}8 & 5 \cdot 4 \pm 0 \cdot 4 & 4 \cdot 0-7 \cdot 5 & 1 \cdot 2 \pm 0 \cdot 1 & 0 \cdot 6-1 \cdot 8 \\ 9 & 6 \cdot 8 \pm 0 \cdot 4 & 4 \cdot 9-9 \cdot 0 & -2 \cdot 5 \pm 0 \cdot 4 & (-1 \cdot 0)-(-4 \cdot 4) \\ 19 & 10 \cdot 1 \pm 0 \cdot 4 & 7 \cdot 4-13 \cdot 4 & -5 \cdot 4 \pm 0 \cdot 4 & (-2 \cdot 6)-(-8 \cdot 4)\end{array}$

Sheep: 7-47 days in lactation, four animals used in all

15
15
11

$$
\begin{aligned}
& 2 \cdot 0-5 \cdot 2 \\
& 3 \cdot 1-9 \cdot 3 \\
& 2 \cdot 7-10 \cdot 8
\end{aligned}
$$

$$
\begin{array}{r}
1.9 \pm 0.2 \\
-4 \cdot 1 \pm 0.5 \\
-5.4 \pm 0.8
\end{array}
$$

$$
\begin{gathered}
0 \cdot 7-2 \cdot 9 \\
(-0 \cdot 4)-(-7 \cdot 5) \\
1 \cdot 0-(-9 \cdot 8)
\end{gathered}
$$

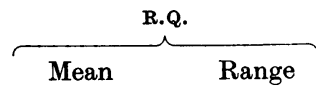

$1 \cdot 32 \pm 0 \cdot 05$
$0 \cdot 82 \pm 0 \cdot 04$
$1 \cdot 32 \pm 0 \cdot 04$

$1 \cdot 22-1 \cdot 49$

$0 \cdot 60-0.94$

$1 \cdot 15-1 \cdot 51$
$1 \cdot 04-1 \cdot 49$

$0 \cdot 74-1 \cdot 18$

$0.91-1 \cdot 63$
The results with all three species were essentially similar as regards the effect of glucose on acetate metabolism. In the rat, mammary tissue which is practically inert towards acetate, will utilize it in presence of glucose without any decrease in R.Q. below the value in glucose; in the rabbit glucose increases the already appreciable acetate utilization, again with maintained R.Q.; while in the sheep, glucose again increases, but relatively slightly, the already considerable acetate uptake, but in this case the R.Q., already $>1$, is raised still further. metabolic difference between mammary tissue from ruminants on the one hand and from non-ruminants (mouse, rat, guinea pig, rabbit) which utilizes glucose as sole substrate with high R.Q. on the other.

The difference is further emphasized by the fact that the situation is reversed when acetate is used as sole substrate. Lactating tissue from ruminants, whether taken in early or late lactation, markedly utilizes acetate with R.Q. $>1$, while slices from fully lactating non-ruminants (rat, rabbit) show a low R.Q. in acetate. However, mammary tissue from 
non-ruminants is not necessarily inert towards acetate, because, while this is more or less true for the rat, rabbit tissue does show an appreciable utilization of acetate, but with R.Q. $<1$.

As we have previously pointed out (Folley \& French, 1949c), it seems reasonable to interpret a high R.Q. obtained under these conditions as indicating net synthesis of fat by the tissue slice, in which case these experiments indicate that ruminant mammary gland is adapted for the synthesis of fat from acetate alone, while non-ruminant mammary tissue is virtually unable to utilize acetate alone for fat synthesis (rat) or at any rate only at a speed perhaps sufficient to give a turnover, detectable by means of tracer isotopes, but not a net synthesis manifested by R.Q. $>1$ (rabbit). In this connexion the known facts regarding the importance of exogenous acetate in ruminant metabolism (Elsden \& Phillipson, 1948) are surely of significance. That similar considerations probably apply to other herbivores which may produce acetate in the caecum (Elsden, Hitchcock, Marshall \& Phillipson, 1946) should be noted in regard to our findings in the rabbit.

Our present results, at any rate as far as ruminants are concerned, provide the first experimental evidence (first reported in preliminary form by Folley \& French, 1948a) in favour of the theory (Folley, 1945), that acetate is utilized by the mammary gland as an important precursor of milk fat, a theory which would explain the high in vivo R.Q. for the ruminant udder. Results for the cow which further support this theory have since been obtained by McClymont (1949), who has observed appreciable A.V. differences in blood acetate across the udder.

Additional support for this theory has recently come from tracer experiments on the pregnant rabbit. It is generally believed that the secretory phase in the mammary gland begins in mid-pregnancy (Turner, 1939) and this is confirmed as regards fat synthesis by the observations of Popják \& Beeckmans (1949a) who found a high rate of incorporation of deuterium into glyceride fatty acids isolated from the mammae of 28-day pregnant rabbits receiving heavy water. The radioactivity of glyceride fatty acids from pregnant rabbits given carboxyl-labelled sodium acetate $\left(\mathrm{CH}_{3}{ }^{14} \mathrm{COONa}\right)$ was much higher than that of fat from foetal tissues or from the maternal liver (Popják \& Beeckmans, 1949b) which strongly suggested the rapid utilization of acetate by the mammary gland itself for milk-fat synthesis even before parturition. It is, of course, probable that some of the fat isolated from the mammae during pregnancy consists of depot fat, but it is certain that a good proportion must have been milk fat since short-chain acids, characteristic of milk fat and absent from depot fat, have been isolated from these fat samples (see above).
Since these tracer studies indicate that active fat synthesis from acetate is already proceeding in the rabbit mammary gland before parturition, and since the initiation of copious lactation results in a striking acceleration of this process, as indicated by the increased respiration and rise of R.Q. above unity observed with rat mammary gland slices incubated with glucose (Folley \& French, 1949d), the low R.Q. exhibited in acetate by mammary slices from lactating rabbits is at first sight somewhat surprising. It must be remembered, however, that in vitro experiments involving one substrate only may have only a limited analogy to in vivo conditions in which a wider range of substrates is available.

Our demonstration that non-ruminant mammary tissue will vigorously utilize acetate in presence of glucose with R.Q. $>1$ does much to harmonize our results on mammary gland slices with the in vivo experiments of Popják \& Beeckmans $(1949 a, b)$, since glucose is available to the gland in the intact animal. Of the two species studied, the effect was more striking in the rabbit in which, on the average, the addition of glucose to $0.1 \%$ caused a decrement in $Q_{\text {acid }}$ amounting to $-6 \cdot 2$ (Table 4), the high R.Q. (in $0.1 \%$ glucose) being maintained. The mean increment in $-Q_{0,}$ amounted to $4 \cdot 0$, which, assuming that glucose is also being oxidized, is quite insufficient to account for the increased acetate utilization in terms of oxidation, which would require $-Q_{\mathrm{O}_{2}}$ to increase by 12.4. The explanation seems inescapable that most of the extra acetate has been utilized for fat synthesis. In the case of the rat the results (Table 3) were qualitatively similar, but the effect not so striking, the mean decrement in $Q_{\text {acid }}$ in four experiments amounting to $-\mathbf{2 \cdot 7}$. Here again the extra oxygen consumption would not suffice for oxidation of the acetate utilized if the glucose were also oxidized. The R.Q. with the mixed substrates was again hardly changed from the value obtained in $0.1 \%$ glucose, so that it appears that even rat mammary tissue, which is virtually inert towards acetate in vitro, can utilize it for fatty-acid synthesis in presence of glucose.

With sheep tissue, which is almost indifferent to glucose, but vigorously utilizes acetate, the addition of glucose to $0.15 \%$ causes a small increase in the acetate uptake above that observed with acetate alone, with a small increase in respiration. The R.Q., however, is appreciably increased above the already high value in acetate (Tables 5 and 6). Thus it may be said that in ruminant and non-ruminant alike, glucose stimulates the utilization of acetate by the mammary gland for milk-fat synthesis.

It must be noted, however, that mammary tissue normally contains small amounts of glycogen (Folley, 1949), and in unpublished determinations we have found rather more in ruminant gland than in tissue from non-ruminants. It is possible, therefore, 
that the apparent difference between mammary tissue from these two types of mammal in the ability to effect fatty acid synthesis from acetate alone is a reflexion of differences in the carbohydrate stores of the tissue. It is true that our results do not exclude the possibility that ruminant mammary tissue devoid, or nearly devoid, of glycogen might be inert in presence of acetate alone, notwithstanding the fact that addition of glucose stimulates still further the incorporation of acetate into fat by ruminant mammary gland slices as indicated by an increase in R.Q. In any case, since $Q_{\mathbf{O}_{2}}$ and R.Q. in glucose alone are low, the most striking effect of glucose on the metabolism of ruminant mammary slices, which we have found so far, is the stimulation of acetate utilization. Therefore, although acetate metabolism may follow a similar course in ruminant and nonruminant mammary tissues, it appears from these experiments that acetate and not glucose is the specific requirement for the synthetic reactions in the ruminant udder which result in a high R.Q.

If it should transpire that likewise in other ruminant tissues acetate, the characteristic product of carbohydrate breakdown in the rumen, is required for metabolic purposes subserved in other animals by blood glucose, these present experiments may have wider implications for an understanding of ruminant biochemistry.

It may be noted that the stimulating effect of carbohydrate on fat synthesis from acetate by liver slices, observed by Bloch \& Kramer (1948), was only manifested by an increased turnover of fat, which can only be detected by means of tracer isotopes. In our experiments the effect is of such a magnitude as to be observable by classical manometric techniques, a fact which, besides indicating the essential similarity of the mechanism of fat synthesis in mammary gland and liver, reinforces our earlier contention (Folley \& French, 1949c) that lactating mammary tissue is peculiarly suitable for in vitro studies of fat synthesis.

The mechanism of the stimulating effect of glucose on fat synthesis from acetate by mammary tissue must be further studied, though a few possibilities should be pointed out. The gland of the non-herbivore seems unable to oxidize acetate, and carbohydrate may be necessary to provide energy without which fat synthesis cannot proceed, as suggested by Bloch (1948) in connexion with fat synthesis by liver slices. Carbohydrate may also be required as a source of additional carbon for fatty acid synthesis. Endogenous acetate is, of course, available in vivo in the rat from the acetate pool, but Bloch (1947) calculates that only some $25 \%$ of the fat synthesized in the body of the rat comes from this source, the rest of the carbon coming presumably from carbohydrate via pyruvate (Bloch, 1948). Though our results indicate that in the ruminant mammary gland, acetate can function not only as the sole source of carbon for fatty acid synthesis but also as a source of energy enabling the synthesis to proceed, it is not unlikely that here too, glucose might help matters by providing additional carbon. Yet another possible role for glucose is worth mentioning. It may provide the glycerol necessary for the synthesis of the glycerides which form the bulk of the milk fat. In a few unpublished experiments we have found that glycerol, under certain conditions, stimulates the utilization of acetate by lactating mammary slices.

In conclusion, it may be well to emphasize that it is not suggested that the whole of the milk fat is synthesized in the mammary gland from acetate or carbohydrate, since the A.v. studies, already mentioned, show clearly that the lactating udder of the ruminant takes up considerable quantities of neutral fat from the blood, much of which must be transformed into milk fat.

\section{SUMMARY}

1. The respiration and the production or utilization of acid by lactating mammary gland slices from ruminants (sheep, goat, cow) and non-ruminants (rat, rabbit) have been studied with acetate and/or glucose as substrates.

2. Mammary tissue from ruminants, whether in early or late lactation, is by contrast with tissue from non-ruminants almost inert towards glucose as shown by low $Q_{\mathrm{O}_{2}}$ values and R.Q. $<1$.

3. Mammary slices from lactating ruminants markedly utilize acetate, $Q_{\mathbf{O}_{2}}$ being greater than values without substrate or in glucose, and R.Q. $>1$. On the other hand, tissue from non-ruminants shows R.Q. $<1$ in acetate, though some acetate is utilized by rabbit tissue and $Q_{\mathrm{O}_{2}}$ is as great as in glucose.

4. Mammary slices from a well-lactating sheep showed a regular increase in $-Q_{\mathrm{O}_{2}}$, R.Q. and acetate utilization $\left(Q_{\mathrm{acjd}}^{\mathrm{o}}\right)$ over the period 7-47 days postpartum, i.e. over the period of increasing milk yield. In glucose $-Q_{\mathrm{O}_{2}}$ and R.Q. were the same as in acetate at the outset, but showed no subsequent increase.

5. Glucose stimulates acetate utilization by mammary slices from rat, rabbit and sheep. In presence of glucose, rat mammary tissue utilized some acetate with R.Q. $>1$ and indeed similar to the value in glucose alone; in rabbit tissue acetate utilization was much increased, again with the high R.Q. maintained; while in the sheep the main effect of glucose was to increase R.Q. over the already high value for acetate alone. In the rat and rabbit the increment in $Q_{\mathrm{O}_{2}}$ was insufficient to account for the increased acetate uptake in terms of oxidation.

6. The results are regarded as evidence of the utilization of acetate for milk-fat synthesis by the mammary gland, and they are discussed from this point of view. 
Our best thanks are due to Dr A. T. Cowie for mammary gland biopsies; to Mr C. P. Cox for the statistical analysis of the sheep data; to Mr S. C. Watson and Miss P. M. Hasker for technical assistance; and to Miss M. Beard and Miss
P. R. M. Taylor for care of the sheep and goats. We are also indebted to Mr A. S. Foot, Prof. H. G. Sanders and officials of the Ministry of Food for making it possible to obtain mammary tissue from slaughtered cows and sheep in milk.

\title{
REFERENCES
}

Barnicoat, C. R., Logan, A. G. \& Grant, A. I. (1949). J. agric. Sci. 39, 44.

Bloch, K. (1947). Physiol. Rev. 27, 574.

Bloch, K. (1948). Cold Spr. Harb. Sym. quant. Biol. 13, 29.

Bloch, K. \& Kramer, W. (1948). J. biol. Chem. 173, 811.

Dickens, F. \& Simer, F. (1931). Biochem. J. 25, 973.

Elliott, K. A C., Benoy, M. P. \& Baker, Z. (1935). Biochem. J. 29, 1937.

Elsden, S. R., Hitchcock, M. W. S., Marshall, R. A. \& Phillipson, A. T. (1946). J. exp. Biol. 22, 191.

Elsden, S. R. \& Phillipson, A. T. (1948). Ann. Rev. Biochem. 17, 705.

Folley, S. J. (1940). Biol. Rev. 15, 421.

Folley, S. J. (1945). In Marshall's Physiology of Reproduction, 3rd ed. chap. 20 (ed. Parkes, A. S.). London: Longmans, Green.

Folley, S. J. (1949). Biol. Rev. 24, 316.

Folley, S. J. \& French, T. H. (1948a). Nature, Lond., 161, 933.

Folley, S. J. \& French, T. H. (1948b). Biochem. J. 42, xlvii. Folley, S. J. \& French, T. H. (1948c). Biochem. J. 43, lv.

Folley, S. J. \& French, T. H. (1949a). Nature, Lond., 163, 174.
Folley, S. J. \& French, T. H. (1949b). Biochem. J. 44, xlv.

Folley, S. J. \& French, T. H. (1949c). Biochem. J. 45, 117.

Folley, S. J. \& French, T. H. (1949d). Biochem. J. 45, 270.

Graham, W. R. Jun., Houchin, O. B., Peterson, V. E. \& Turner, C. W. (1938). Amer. J. Physiol. 122, 150.

Hilditch, T. P. (1947). The Chemical Constitution of Natural Fats, 2nd ed. London: Chapman and Hall.

Kleinzeller, A. (1943). Biochem. J. 87, 674.

Krebs, H. A. \& Henseleit, K. (1932). Hoppe-Seyl. Z. 210, 33.

McClymont, G. L. (1949). Biochem. J. 45, i.

Popják, G. \& Beeckmans, M.-L. (1949a). Biochem. J. 44, xxxvi.

Popják, G. \& Beeckmans, M.-L. (1949b). Biochem. J. 44, xxxvii.

Popják, G., Folley, S. J. \& French, T. H. (1949). Arch. Biochem. 83, 508.

Reid, R. L. (1950). Nature, Lond., 165, 448.

Reineke, E. P., Stonecipher, W. D. \& Turner, C. W. (1941). Amer. J. Physiol. 182, 535.

Rittenberg, D. \& Bloch, K. (1945). J. biol. Chem. 160, 417.

Turner, C. W. (1939). Sex and Internal Secretions, 2nd ed. chap. 11 (ed. Allen, E.). London: Baillière, Tindall \& Cox.

\section{A Chemical Study of Rabbit Antiovalbumin}

\author{
BY R. R. PORTER* \\ Biochemical Laboratory, University of Cambridge
}

(Received 25 October 1949)

There are three main theories purporting to explain the formation of antibodies in an animal in response to the injection of an antigen. All accept the principle that combination of antibody with antigen depends on the configuration of parts of the antibody molecule being complementary to parts of the antigen molecule. The theory due to Breinl \& Haurowitz (1930) and Mudd (1932) postulated that the specific configuration of the antibody arose because the antigen acted as template around which the protein-synthesizing system made new antibody. Burnett (1941) offered criticism of the theory and suggested that the protein-synthesizing system itself, was modified by contact with antigen. Pauling (1940) brought forward a different theory, in which the formation of antibody was regarded as due to refolding of preformed $\gamma$-globulin, in the presence

* Present address: National Institute for Medical Research, Mill Hill, London, N.W. 7. of antigen, into a new configuration complementary to that of the antigen. An apparently successful attempt to demonstrate this mode of formation in vitro (Pauling \& Campbell, 1942) has not been confirmed (Campbell, 1948); moreover, the theory fails to explain many characteristics of immunity (Burnett, 1941) such as: (1) the persistence of antibodies in: plasma for considerable periods after the last known contact with antigen; (2) the difference between primary and secondary response to injection of antigen; (3) the increase in antibody titre after bleeding of the animal; (4) the increase in concentration of non-specific serum globulin during immunization; (5) the evidence that the site of antibody formation is localized; (6) the demonstration that antibody can retain its specific action after denaturation (Erickson \& Neurath, 1945).

Pauling's theory postulates only a change in the physical state during transformation of $\gamma$-globulin 